\title{
Whether of Sharia Stock and Corporate Sukuk Play a Role in The Investment Yield Sharia Insurance in Indonesia
}

\author{
Muammar Khaddafi ${ }^{1}$, Iskandar Muda ${ }^{2}$, Mohd. Heikal ${ }^{3}$ Wahyuddin ${ }^{1}$ and Falahuddin ${ }^{3}$ \\ \{khaddafi@unimal.ac.id, iskandar1@usu.ac.id, mohd.heikal@unimal.ac.id\} \\ ${ }^{1}$ Faculty of Economics, Department of Accounting, Universitas Malikussaleh, Indonesia \\ 2 Universitas Sumatera Utara, Medan, Indonesia \\ ${ }^{3}$ Faculty of Economics, Department of Accounting, Universitas Malikussaleh,Indonesia

\begin{abstract}
This study aims to analyzed of the effect of Gross Sharia Stock and Corporate Sukuk to The Investment Yield Sharia Insurance in Indonesia. Using a causal research design in Indonesia Sharia Insurance from Financial Services Authority (OJK) Indonesia use for this research with used Smart PLS software. The results show that Gross Sharia Stock and Corporate Sukuk influence to Investment Yield Sharia Insurance in Indonesia. The data taken within a short span of 2 years. The implications for Indonesian Financial Services Authority in regulating and governance of stocks and Sukuk in the insurance industry in Indonesia. The results findings that Gross Sharia Stock as a variable considered in generating investment in sharia industry in Indonesia.
\end{abstract}

Keywords: Investment Yield, Sharia Stock, Corporate Sukuk

\section{Introduction}

Sharia Shares are securities proof of equity participation of a company with profit sharing system. The shares must also be issued by companies engaged in the lawful business. Shariah Bond is a certificate of a particular asset with a profit-sharing system (A. Ahmed, 2004; M. Ahmed, 2004; Chapra, 2008; Čihák and Hesse, 2008; Kia, 2013; Muda and Dharsuky, 2015; Muda and Nurlina, 2018; Muda and Windari, 2018). This is different from conventional bonds that are debt or interest-bearing loans. The Sukuk funds must also be for a halal business activity (Siddiqi, 1996; Metwally, 1997; Smith, 2002; Shakespeare, 2006). While Sharia Mutual Fund is an investment alternative for investors, especially small investors and investors who much time and expertise to calculate the risk of their investment, so should be assisted by an investment manager. Unlike conventional mutual funds where investment managers who manage investor funds can be free to buy all sorts of shares, for Islamic mutual funds, investment managers must selectively choose Sharia stocks (Usmani, 1998; Story, Thomas Jr. and Schwartz, 2010; Tabash, 2014). Sharia shares do not recognize riba (interest) as well as conventional stocks, but rather adopt a profit-sharing system (ratios) between investors and publicly traded companies issuing securities for trading in the capital market (Zaman, 1993; Warde, 2000) Such a system is also known as musharaka or syirkah. If a publicly funded investor company reaps profits, the investor will enjoy the benefits. Conversely, if the related company suffered losses, investors must also share the loss. Although the value of profit to be obtained by customers is fluctuating company performance, but the portion of the profit to be earned or the risks that will be borne by investors and issuers has been agreed at the beginning through a contract promise (Smith, 2002). The condition is 
different from the conventional stocks that apply so that it can provide a more stable profit value for investors affected by the performance of the issuer.

To implement the investment call, it must create a means to invest. Many people choose to invest. One form of investment is to invest in the capital market (Shakespeare, 2006). The capital market is basically a market for various financial instruments or long-term securities that can be traded, either in the form of debt or own capital. The capital market is one of the important pillars in the world economy today. Many industries and companies use intermediary as a medium to absorb investments and media to strengthen their financial position. The presence of shariah capital markets that provide peace and confidence for halal transactions. The opening of the Jakarta Islamic Index in Indonesia (JII) in 2000 as a syariah capital market gives investors the opportunity to invest funds in companies that conform to sharia principles. Various products are offered in syariah index in JII and ISSI such as stocks, bonds, sukuk, mutual funds sharia.

\section{Methodology}

The research analysis is conducted on planning, supporting factors and outcomes. The results of comparative analysis can find the elements or important factors that lie behind the cultivation and difference (Sirojuzilam and Muda, 2016; Tarmizi, Daulay and Muda., 2016; Dalimunthe, Fadli and Muda, 2016; Gusnardi and Muda, 2016; I. Muda et al., 2016; Iskandar Muda, Sihombing, et al., 2016; Muda, Rahmanta and Marhayanie, 2017; Azlina et al., 2017; Badaruddin et al., 2017; Muda, Ismail and Marhayanie, 2017; Sirojuzilam and Muda, 2017; Nurlina and Muda, 2017; Saputra and Muda, 2017; Sihombing et al., 2017; Dalimunthe and Muda, 2017; Erlina, Tarigan and Muda, 2017; Ferine, Ermiaty and Muda, 2017; Muda, Rahmanta, et al., 2018; Muda, Siregar, et al., 2018; Muda and Hutapea, 2018). Comparative causal research is an expost facto, meaning that data that have occurred This research process with systematic empirical research in which the researcher does not control directly because the embodiment of the variable has occurred or the variable is basically cannot be manipulated (Muda and Naibaho, 126AD; Lubis, Lubis and Muda, 2016; Lubis, Torong and Muda, 2016; Lutfi, Nazwar and Muda, 2016; Handoko and Muda, 2017; Hasan, Gusnardi and Muda, 2017; Muda et al., 2017; Hutagalung et al., 2017; Lubis, Rustam and Muda, 2017; Marhayanie and Muda, 2017; Khaddafi et al., 2018; Muda and Hasibuan, 2018). The data used are secondary data sourced from the Financial Services Authority Republic of Indonesia from January 2016September 2017.

\section{Result And Discussion \\ 3.1. $\quad$ Result}

The coefficient result 0.005 value $<5 \%$ the decision is reject $\mathrm{H}_{0}$ and the hypothesis $\mathrm{Ha}$ accepted (Iskandar Muda, Panjaitan, et al., 2016; Nurzaimah, Rasdianto and Muda, 2016; Nasir, Basri and Muda, 2017; Sadalia, Rahamani and Muda, 2017; Situmorang, Rini and Muda, 2017; Yahya, Torong and Muda, 2017; Muda, Harahap, et al., 2018; Muda, Roosmawati, et al., 2018; Pohan et al., 2018). The result of $t$ value in the table path coefficients is presented in the following in Figure 1 and Table 1: 


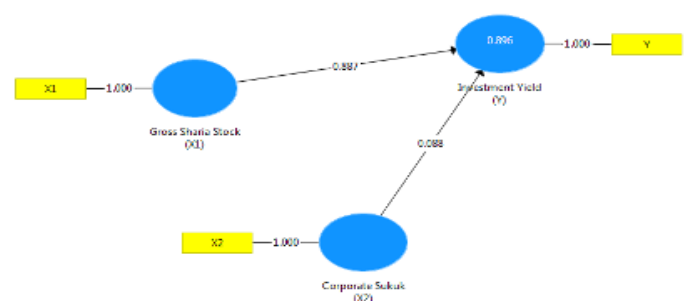

Fig. 1. Overall Model with Coefecient

The effect test as following :

Table 1. The result of Bootsraping

\begin{tabular}{lll}
\hline & $t$ & $\mathrm{P}$ \\
& Statistics & Values \\
\hline $\begin{array}{l}\text { Corporate Sukuk (X) } \\
\text { Investment Yield (Y) }\end{array}$ & $->, 886$ & 0,376 \\
\hline $\begin{array}{l}\text { Gross Sharia Stock }\left(\mathrm{X}_{1}\right) \\
\text { Investment Yield (Y) }\end{array}$ & 10,406 & 0,000 \\
\hline
\end{tabular}

The results show that Gross Sharia Stock influence to Investment Yield Sharia Insurance in Indonesia. The inner model generated from evaluation is presented in the following Figure 2 and Table 2 :

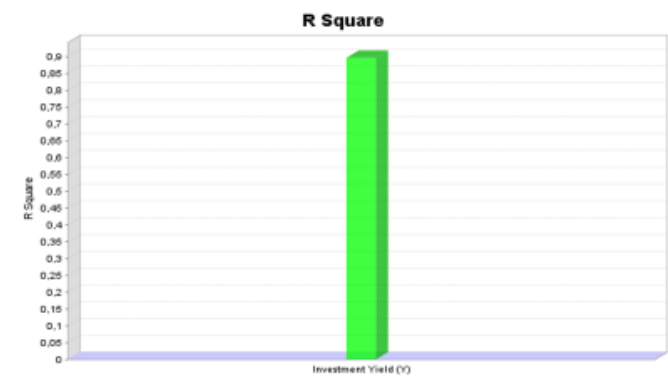

Fig. 2. F Square

Table 2. R-Square Value

\begin{tabular}{ll} 
& R Square Adjusted \\
\hline Investment Yield (Y) & 0,885 \\
\hline
\end{tabular}

The variation of R-Square value of $89.6 \%$. The existence of Gross Sharia Stock give Contribution On Investment Yield Sharia Insurance.

\subsection{Discussion}

Sukuk is not a bond, each published sukuk as underlying asset. Proprietary claim on Sukuk is based on asset/project. The use of Sukuk funds should be used for Halal business activities. Remuneration for margin. Shares constitute securities of proof of equity participation to the company and with the proof of such participation obtain a share of the 
business. The concept of capital participation with the right part of the results as Musharaka or Syirkah. However, not all shares issued by Issuers may be referred to as sharia shares.

\section{Conclusions}

The Gross Sharia Stock influence to Investment Yield Sharia Insurance in Indonesia. The study has limitations taken within a short span of 2 years. The implications of this research can be used by the regulating the governance of stocks and Sukuk in the insurance industry in Indonesia.

\section{References}

[1] Ahmed, A. (2004) Role of Zakah and Awqaf in Poverty Alleviation, Islamic Development Bank Group Islamic Research and Training Institute. doi: http://dx.doi.org/10.1016/j.biortech.2015.03.111.

[2] Ahmed, M. (2004) 'Islamic versus traditional banking in Arab region: premises and promises', in International Seminar on "The Prospects of Arab Economic Cooperation. Alexandria.

[3] Azlina, N., Hasan, A., Desmiyawati and Muda, I. (2017) 'The effectiveness of village fund management (case study at villages in coastal areas in Riau)', International Journal of Economic Research, 14(12), pp. 325-336. doi: 10.1111/ele.12484.

[4] Badaruddin, B., Revida, E., Ermansyah, E. and Muda, I. (2017) 'Village governance with implementation of law number 6 of 2014 on the village and village administration', International Journal of Economic Research, 14(17), pp. 389-402.

[5] Chapra, M. U. (2008) 'The Global Financial Crisis: Can Islamic Finance Help Minimize the Severity and Frequency of Such a Crisis in the Future?', in Forum on the Global Financial Crisis. Islamic Development Bank.

[6] Čihák, M. and Hesse, H. (2008) Islamic Banks and Financial Stability: An Empirical Analysis. WP/08/16. doi: 10.1080/09540121.2015.1120266.

[7] Dalimunthe, D. M. J. far, Fadli, F. and Muda, I. (2016) 'The application of performance measurement system model using Malcolm Baldrige Model (MBM) to support Civil State Apparatus Law (ASN) number 5 of 2014 in Indonesia', International Journal of Applied Business and Economic Research, 14(11), pp. 7397 7407.

[8] Dalimunthe, D. M. J. and Muda, I. (2017) 'The Empirical Effect of Education and Training to The Performance of Employees', International Journal of Economic Research, 14(21), pp. 403-413.

[9] Erlina, Tarigan, Z. A. and Muda, I. (2017) 'Antecedents of budget quality empirical evidence from provincial government in Indonesia', International Journal of Economic Research, 14(12), pp. 301-312.

[10] Ferine, K. F., Ermiaty, C. and Muda, I. (2017) 'The Impact of Entrepreneurship and Competence On Small Medium Enterprises Tangan Di Atas Medan Entrepreneurs' Work Performance', International Journal of Economic Research., 14(6), pp. 380-393.

[11] Gusnardi, R. R. and Muda, I. (2016) 'Competency mapping and analysis of students competency based on economics subject national examination and its alternative solutions in state high schools at Pekanbaru.', International Journal of Economic Research, 3(5), p. 2133-2148.

[12] Handoko, B. and Muda, I. (2017) 'Difference Analysis of Consumer Perception of 
Motorcycle Product Quality', International Journal of Economic Research, 14(14), pp. 363-379.

[13] Hasan, A., Gusnardi and Muda, I. (2017) 'Analysis of taxpayers and understanding awareness increase in compliance with taxpayers individual taxpayers', International Journal of Economic Research, 14(12), pp. 75-90.

[14] Hutagalung, B., Dalimunthe, D. M. ., Pambudi, R., Hutagalung, A. Q. and Muda, I. (2017) 'The Effect of Enterpreneurship Education and Family Environment Towards Students' Entrepreneurial Motivation', International Journal of Economic Research, 14(20), pp. 331-348.

[15] Khaddafi, M., Wahyuddin, Heikal, M., Falahuddin and Maulida, R. (2018) 'Effect of corporate governance mechanism, independence and management of earnings integrity of financial statements (In manufacturing companies listed on the stock exchange)', Quality - Access to Success, 19(164), pp. 94-97.

[16] Kia, A. (2013) Islam and the Stock Market in Islam and the economy. Edited by M. K. Hassan and M. K. Lewis. Oxford: Oxford University Press.

[17] Lubis, A. F., Lubis, T. A. and Muda, I. (2016) 'The role of Enterprise Resource Plan (ERP) configuration to the timeliness of the financial statement presentation', International Journal of Applied Business and Economic Research, 14(11), pp. 75917608.

[18] Lubis, A., Rustam, R. and Muda, I. (2017) 'Factors Affecting The Cost of Agency of Village Owned Enterprise’, International Journal of Economic Research, 14(21), pp. 151-166.

[19] Lubis, A., Torong, Z. B. and Muda, I. (2016) 'The urgency of implementing balanced scorecard system on local government in North Sumatra - Indonesia', International Journal of Applied Business and Economic Research, 14(11), pp. 7575-7590.

[20] Lutfi, M., Nazwar, C. and Muda, I. (2016) 'Effects of investment opportunity set, company size and real activity manipulation of issuers in Indonesia Stock Exchange on stock price in Indonesia', ". International Journal of Economic Research, 13(5), pp. 2149-2161.

[21] Marhayanie, M. I. and Muda, I. (2017) 'Impact of The Online Car Rental Service Order System on Sales Turnover with Financial Literacy Customer as Intervening Variables', International Journal of Economic Research, 14(21), pp. 317-332.

[22] Metwally, M. M. (1997) 'Economic consequences of applying Islamic principles in Muslim societies', International Journal of Social Economics, 24(7/8/9), pp. 941-957. doi: 10.1108/03068299710178955.

[23] Muda, I. and Dharsuky, A. (2015) 'Impact of Region Financial Information System (SIKD) Quality, Role Ambiguity and Training on Precision of Financial Statement of Local Government Presentation In North Sumatra', International Journal of Applied Business and Economic Research, 13(6), pp. 4283-4304.

[24] Muda, I., Dharsuky, A., Sadalia, I. and Siregar, H. . (2016) 'Impact of capital investments and cash dividend policy on Regional Development Bank PT. Bank Sumut to the district own source revenue and economic growth', International Journal of Applied Business and Economic Research, 14(11), pp. 7863-7880.

[25] Muda, I., Dharsuky, A., Siregar, H. S. and Sadalia, I. (2017) 'Combined Loadings and Cross-Dimensional Loadings Timeliness of Presentation of Financial Statements of Local Government', in IOP Conf. Series: Materials Science and Engineering 180, pp. 1-6. doi: 10.1088/1742-6596/755/1/011001.

[26] Muda, I., Harahap, A. H., Erlina, Ginting, S., Maksum, A. and Abubakar, E. (2018) 
'Factors of quality of financial report of local government in Indonesia', in $i O P$ Conference Series: Earth and Environmental Science PAPER, pp. 1-7. doi: 10.1088/1755-1315/.

[27] Muda, I. and Hasibuan, A. N. (2018) 'Public Discovery of the Concept of Time Value of Money with Economic Value of Time', in Proceedings of MICoMS 2017. Emerald Group Publishing Limited, pp. 251-257. doi: 10.1108/978-1-78756-793-1-00050.

[28] Muda, I. and Hutapea, A. A. F. (2018) 'Influence of capital expenditure and income original region to the income per capita in Indonesia', IOP Conference Series: Earth and Environmental Science PAPER, 126, pp. 1-7. doi: 10.1088/1755-1315/.

[29] Muda, I., Ismail, M. and Marhayanie, M. (2017) 'Impact Allocation Capital Expenditure on The Improvement of the Local Government Assets in North Sumatra and Effect on Local Revenue Sustainability', International Journal of Economic Perspectives, 11(2), pp. 110-123.

[30] Muda, I. and Naibaho, R. (126AD) 'Variables influencing allocation of capital expenditure in Indonesia', in IOP Conference Series: Earth and Environmental Science PAPER, pp. 1-9. doi: 10.1088/1755-1315/.

[31] Muda, I. and Nurlina, N. (2018) 'Influence of Manufacture of Textiles, Clothing, and Leather and Manufacture of Paper, Printing, and Publishing on Economic Growth', in Emerald Reach Proceedings Series. EmeraldPublishingLimited, pp. 107-113. doi: 10.1108/978-1-78756-793-1-00048.

[32] Muda, I., Panjaitan, R., Erlina, E., Ginting, S., Maksum, A. and Abubakar, A. (2016) 'Model application of Murabahah financing acknowledgement statement of Sharia accounting standard No 59 Year 2002', IOP Conference Series: Earth and Environmental Science, 41(12), pp. 331-335. doi: 10.1088/1755-1315/.

[33] Muda, I., Rahmanta, Marhayanie and Putra, A. S. (2018) 'Institutional Fishermen Economic Development Models and Banking Support in the Development of the Innovation System of Fisheries and Marine Area in North Sumatera', IOP Conference Series: Materials Science and Engineering, 288(1), pp. 1-7. doi: 10.1088/1757899X/288/1/012082.

[34] Muda, I., Rahmanta, S. A. and Marhayanie, M. (2017) 'The Role of Working Capital, Productivity, Applied Technology and Selling Market Prices on Fisherman's Revenues', International Journal of Economic Research, 14(20), pp. 85-97.

[35] Muda, I., Roosmawati, F., Siregar, H. S., Ramli, Manurung, H. and Banuas, T. (2018) 'Performance Measurement Analysis of Palm Cooperative Cooperation with Using Balanced Scorecard', IOP Conference Series: Materials Science and Engineering, 288(1). doi: 10.1088/1757-899X/288/1/012081.

[36] Muda, I., Sihombing, M., Jumilawati, E. and Dharsuky, A. (2016) 'Critical success factors downstream palm oil based Small and Medium Enterprises (Sme) in Indonesia', International Journal of Economic Research, 13(8), pp. 3531-3538.

[37] Muda, I., Siregar, H. S., Sembiring, S. A., Ramli, Manurung, H. and Zein, Z. (2018) 'Economic Value of Palm Plantation in North Sumatera and Contribution to Product Domestic Regional Bruto', IOP Conference Series: Materials Science and Engineering, 288(1). doi: 10.1088/1757-899X/288/1/012080.

[38] Muda, I. and Windari (2018) 'Dimension of an Islamic Model Value on the Existence of Syariah Walmart', in Emerald Reach Proceedings Series. EmeraldPublishingLimited, pp. 317-322. doi: 10.1108/978-1-78756-793-1-00081.

[39] Nasir, A., Basri, Y. M. and Muda, I. (2017) 'Effectiveness of Potential Tax Region as the Real Local Revenue Sources in Riau Coastal Area', International Journal of 
Economic Research, 14(2), pp. 313-324.

[40] Nurlina, N. and Muda, I. (2017) 'The Analysis of The Effects of Capital Expenditure and Human Development Index on Economic Growth and Poverty in East Aceh Regency', International Journal of Economic Research, 14(16), pp. 395-409.

[41] Nurzaimah, Rasdianto and Muda, I. (2016) 'The skills and understanding of rural enterprise management of the preparation of financial statements using Financial Accounting Standards financial statement on the Entities without Public Accountability framework on the implementation of village admini', International Journal of Applied Business and Economic Research, 14(11), pp. 7417-7429.

[42] Pohan, N., Badaruddin, Dalimunthe, R. F., Purwoko, A. and Muda, I. (2018) 'The effects of human resource development and institutional arrangements on performance, service quality and area development in indonesia', Quality - Access to Success, 19(163), pp. 94-103.

[43] Sadalia, I., Rahamani, N. A. B. and Muda, I. (2017) 'The significance of internet based financial information disclosure on corporates' shares in Indonesia', International Journal of Economic Research, 14(12), pp. 337-346.

[44] Saputra, E. A. and Muda, I. (2017) 'The Analysis of the Influencing Factors of Budget Absorption', International Journal of Economic Research, 14(12), pp. 287-300.

[45] Shakespeare, R. (2006) An Islamic Money Supply as the Means to Integration. 7HUFIslamicFinance-rs-0603. Havard.

[46] Siddiqi, M. N. (1996) Role of Fiscal Policy in Controlling Inflation in Islamic Framework, S. Available at: http://www.siddiqi.com/mns/FiscalPolicy.html (Accessed: 11 January 2019).

[47] Sihombing, M., Muda, I., Jumilawati, E. and Dharsuky, A. (2017) 'Factors Affecting The Success of Local Innovation Systems with Government Programs As Moderators', International Journal of Economic Research, 14(21), pp. 272-289.

[48] Sirojuzilam, H. and Muda, I. (2016) 'Identification of factors of failure of Barisan Mountains Agropolitan area development', International Journal of Economic Research, 13(5), pp. 2163-2175.

[49] Sirojuzilam, H. and Muda, I. (2017) 'Effect of Private Collaborative as a Moderation of Success of Agropolitan', International Journal of Economic Research, 14(20), pp. $463-475$.

[50] Situmorang, S. H., Rini, E. S. and Muda, I. (2017) 'Customer Experience, Net Emotional Value and Net Promoter Score on muslim middle class women in Medan', International Journal of Economic Research, 14(20), pp. 269-283.

[51] Smith, R. (2002) 'Ex-Analyst at BNP Paribas Warned His Clients in August About Enron - WSJ', Wall Street Journal, 78(2), pp. 15-29. Available at: https://www.wsj.com/articles/SB1012256641589759400 (Accessed: 11 January 2019).

[52] Story, L., Thomas Jr., L. and Schwartz, N. . (2010) Wall St. Helped Greece to Mask Debt Fueling Europe's Crisis - The New York Times, GLOBAL BUSINESS. Available at: https://www.nytimes.com/2010/02/14/business/global/14debt.html (Accessed: 14 January 2019).

[53] Tabash, M. I. (2014) 'The Relevance of Islamic Finance Principles in Economic Growth', International Journal of Emerging Research in Management \&Technology, 9359(2), pp. 49-54. Available at: http://www.ermt.net.

[54] Tarmizi, H. B., Daulay, M. and Muda., I. (2016) 'The influence of population growth, economic growth and construction cost index on the local revenue of tax on acquisition of land and building after the implementation of law no. 28 of 2009', International 
Journal of Economic Research, 13(5), pp. 2285-2295.

[55] Usmani, M. M. T. (1998) An introduction to Islamic finance. Karachi: Maktaba Ma'ariful Qur'an.

[56] Warde, I. (2000) Islamic finance in the global economy. Edinburgh: Edinburgh University Press.

[57] Yahya, I., Torong, M. Z. B. and Muda, I. (2017) 'Influence behavior in legislature budget development of regions in the province of aceh and North Sumatra', International Journal of Economic Research, 14(8), pp. 147-156.

[58] Zaman, S. M. H. (1993) 'Indexation of Financial Assets: An Islamic Evaluation', $J$. Res. Islamic Econ, 2(2), pp. 31-49. doi: 10.1007/BF00810591. 
